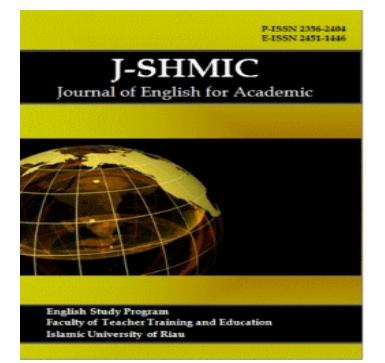

J-SHMIC : Journal of English for Academic

ISSN : 2641-1446 (Online) ISSN :2356-2404 (Print)

Homepage: https://journal.uir.ac.id/index.php/jshmic

Vol 9 No 1, February 2022

\title{
An Analysis of Indonesian-English Code Mixing Used in Social Media (Twitter)
}

\author{
Cindy Nabila ${ }^{1}$, Andi Idayani ${ }^{2}$ \\ Universitas Islam Riau ${ }^{l, 2}$ \\ cindynabila150@gmail.com1; andiidayani@edu.uir.ac.id ${ }^{2}$
}

\begin{abstract}
This study entitled An Analysis of Indonesian-English Code Mixing on Social Media, was examined by the researcher (Twitter). The goal of this study is to determine the form and function of Indonesian-English code mixing on Twitter. A descriptive qualitative method was used to perform this study. The data for this study employed the tweets of influential people on Twitter. The instrument utilized by this researcher was documentation. The tweets of influential people on Twitter were used to collect data for this study. This researcher used documentation as an instrument. This study was conducted entirely online, with a focus on Twitter. The researcher took screenshots of the influencers' tweets. The data was then categorized as code mixing by the researcher. The researcher found some relevant purpose of code mixing in Twitter. They are: need feeling motive, being more informative, making jokes, expressing self emotion.
\end{abstract}

\begin{abstract}
ABSTRAK
Peneliti menganalisis penelitian ini yang berjudul Analisis Campur Kode Bahasa Indonesia-Inggris yang Digunakan di Media Sosial (Twitter). Penelitian ini bertujuan untuk mengetahui bentuk dan tujuan campur kode bahasa Indonesia-Inggris di media sosial twitter. Penelitian ini dilakukan dengan Metode Deskriptif Kualitatif. Sumber data dalam penelitian ini diambil dari tweet para influencer di twitter. Peneliti ini menggunakan dokumentasi sebagai instrumennya. Penelitian ini dilakukan secara online khususnya melalui twitter. Peneliti mengambil screenshot twit para influencer. Kemudian peneliti mengklasifikasikan data tersebut ke dalam bentuk campur kode. Hasil penelitian menunjukkan bahwa ada enam bentuk campur kode di Twitter, seperti: campur kode data Word 53, campur kode data Frase 20, campur kode data Hybrid 8, campur kode data Reduplikasi Kata 1, campur kode Idiom 7 data, campur kode data Klausul 25. Peneliti menemukan beberapa tujuan yang relevan dari campur kode di Twitter diantaranya: motif kebutuhan perasaan, menjadi lebih informatif, membuat lelucon, mengekspresikan emosi diri.
\end{abstract}

\section{KATA KUNCI}

analisis, campur kode, media sosial (Twitter) 


\section{INTRODUCTION}

Language is a fundamental ability for effective interpersonal communication. People use language to communicate their ideas, thoughts, feelings, desires, and emotions to others, as well as to get information. Language has a social role by allowing individuals to connect with one another. In today's world, most individuals can speak in many languages, such as in Indonesia. As a result, most Indonesians prefer to communicate in more than one language, whether speaking or writing. In the process of human connection with one another, language is regarded to play a crucial function. Because various regions speak different languages, and sociolinguistics is the study of public languages. In Indonesia, English is considered a foreign language. The language that is taught at the educational level to students or persons for the purpose of practical communication. English is one of several languages that has become a vital demand as a task of international languages throughout the world (Surtrismi, 2014)

Furthermore, members of a bilingual community differ in their ability to learn the languages spoken in the community, they must be able to create an environment in which they can effectively communicate. They are compelled to code-mix as a result of this circumstance. They have a tendency to combine words or phrases from other languages into their own. When someone want to express something in English that they can't say in Indonesian, they'll say it in English or vice versa. Code mixing is the term for this phenomena. A code is a technique for communication between two or more persons that may be utilized on any occasion (Hanafiah et al., 2018). Following that, Diana Kartini (2019) claims that everyone uses code mixing for different reasons. It might be a need or a matter of dignity. Need filling is a motivation when people are unable to discover terms in their language that have a similar meaning. When people appear in their educational standing, dignity filling is applied.

According to (Pratapa et al., 2018) Code-switching or code-mixing (CM) refers to the juxtaposition of linguistic units from two or more languages in a single conversation or sometimes even a single utterance. It is quite commonly observed in speech conversations of multilingual societies across the world. According to Grosjean (1982) cited in (Hanafiah et al., 2018) backs this up by pointing out that code-mixing is concerned with moving or transferring materials from a lexical item to a sentence, whereas language alternation is concerned with switching between two languages inside a single discourse. Code mixing is used not just in direct speech, but also in indirect communication, such as on Twitter, Instagram, Facebook, Youtube, and WhatsApp. In a chat, individuals may mix languages directly or indirectly. In today's world, including Indonesia, Twitter is one of the most popular social networking platforms. Researcher choose influencers on Twitter, namely Tsana, Jiemi Ardian, Mario Teguh, Nago Tejena, Handoko Tjung, Bayu Joo, and Afutami. They are the ones who frequently update their tweets on twitter using code mixing.

In addition, Twitter is also a platform where people can express their emotions, whether they are joyful, hilarious, or sad. In utilizing Twitter, all of this comes back to the user. Influencers might have a closer relationship with their fans. They can also react to or remark on fresh tweets. As a result of Twitter's trending capabilities, users can see what is trending in Indonesia. We can do anything with Twitter since we can communicate without needing to meet face to face or even if we have never met. According to (Krutka, 2014) Twitter was originally fashioned to allow users to send "small bursts of information," known as "tweets," about daily events to other users of the service. 
This research would be focused on the Indonesian-English Code Mixing used in Social Media (Twitter). The emphasis of the study English code mixing and forms of code mixing in tweets on Tsana, Jiemi Ardian, Mario Teguh, Nago Tejena, Handoko Tjung, Bayu Joo, and Afutami twitters. This study has general objectives is to found out the forms of IndonesianEnglish code mixing used by influencers on twitter and To found out purposes of English code mixing used by influencers onTwitter.

Socioliguistics is the study of how language operates in our everyday lives in our informal interactions and the media we are exposed to, as well as the existence of social norms, regulations, and laws that address language, (Wardhaugh and Fullerm, 2015) write. It means that sociolinguistics is the study of how the culture of a society effects the terminology we use in our language. According to Fishman in Rahardi (2010), "Sociolinguistics is the study of the properties of language varieties, the characteristics of their functions, and the characteristics of their speakers as these three interact, alter, and modify each other within a speech community". The phrase suggests that sociolinguistics is the study of the interaction and modification of three elements within a speech community: language diversity traits, function qualities, and speakers who constantly interact and alter one another.

\section{Code Mixing}

Code mixing refers to the use of one language in another, as well as the blending of more than two languages or linguistic differences in a single utterance. Code mixing happens when people who speak two languages are unable to communicate successfully. "The bulk of mixing is lexical in nature," according to Hamers and Blanc's study published in Bi (2011). "Nouns are the most often exchanged words." Code mixing, in a nutshell, is the act of translating words or phrases from one language into another. It refers to the technique of combining two or more languages without altering the subject. People frequently blend their languages, particularly with English. In Indonesia, most people mix language in their conversation such as in the following example:

1) Apakah kalian sudah ready?

2) Good night, sampai jumpa besok ya!

3) Eh udah lama gak selfie $n i$.

4) Post aja ya, bagus kok.

Because the term is divided between two distinct languages, the sample from 1 to 4 with the underlined text provides an example of code mixing (Indonesian and English). As previously mentioned, code mixing is the use of two or more languages in speech by shifting one or more linguistic components from one language to another without changing the meaning of the phrase since the pieces only support the sentence of another language presented. The constituents of a single language serve no special purpose.

According to Suwito (1985), cited in Siskawati (2012), there are six forms of code-mixing: Insertion of Word, Insertion of Phrase, Insertion of Hybrid, Insertion of Word Reduplication, Insertion of Idiom, and Insertion of Clause.

\section{Insertion Of Word}

One method of code-mixing is to insert English terms into Indonesian sentences. The insertion of a word can be regarded as grammatical structure.

a) Datanglah ke party ku malam ini. 
Based on the example above, that there is a mix of Indonesian-English in the sentence. The word Datanglah ke is Indonesian and the word party in the middle is English. By placing a party between that sentences it is called Insertion of Word CodeMixing. The underline word party it means social event.

\section{Insertion Of Phrase}

Phrase is grammatical analysis to refer to a single element of structure typically containing more than one word, and lacking the subject and predicate structure typical of clauses.

a) Perusahaan ini membutuhkan fresh graduate yang berkompeten.

Based on the example above, we can see that there is a mix of Indonesian-English in the sentence. The word perusahaan ini membutuhkan is Indonesian and the word fresh graduate in the middle is English. By placing a fresh graduate between that sentences it is called Insertion of Phrase Code Mixing. The underlineword fresh graduate it means finished from College or University.

\section{Insertion of Hybrid}

Hybrid refers to the part of a word that is made up of several parts. A hybrid is created when two elements from different languages are blended to create meaning.

a) Jadi orang itu jangan suka ngejudge orang lain.

Based on the sentence above, we can see that there is a mix of Indonesian-English in the sentence. The word jadi orang itu jangan suka is Indonesian and the word nge-judge in the middle is English. By placing a nge-judge between that sentences it is called Insertion of Hybrid Code Mixing. The underline word ngejudge consist of twolanguage which combine nge in Indonesia is suffix judge in english is noun.

\section{Insertion of Word Reduplication}

Word reduplication is the process of turning one word into two words in a single sentence or utterance. It indicates that the speaker repeats the same word in a phrase several times.

a) Bagaimana kabar kamu, fine-fine aja kan?

Based on the example, we can see that there is a mix of Indonesian- English in the sentence. The word bagaimana kabar kamu is Indonesian and the word fine-fine in the middle is English. By placing a fine-fine between that sentences it is called Insertion of Word Reduplication Code Mixing. The underline word fine and fine it means everything it's oke.

\section{Insertion of Idiom}

Idiom is a collection of words that have distinct meanings than the individual terms. It means that idiom gives each word a new meaning that is distinct from its original meaning.

a) Semuanya akan baik-baik saja jika kamu go with the flow.

Based on the sentence above, we can see that there is a mix of Indonesian-English in the sentence. The word semuanya akan baik- baik saja jika kamu is Indonesian and the word go with the flow in the last sentence is English. By placing a go with the flow between that sentences it is called Insertion of Idiom Code Mixing. Theunderline word go with the flow it means let things happen.

\section{Insertion of Clause}

A clause is a grammatical unit that consists of a subject and a verb. Clauses can be classified into two groups. The first clause is self-contained, whereas the second is reliant. An independent clause is a complete sentence that comprises the main subject and verb of the phrase (it is also called a main clause). Even though it is not a complete sentence, the dependent clause must be connected to an independent clause.

a) What will you do jika kamu menemukan uang di jalan? 
Based on the example above, we can see that there is a mix of Indonesian-English in the sentence. The word jika kamu menemukan uang di jalan is Indonesian and the word what will you do in the first sentence is English. By placing a what will you do between that sentences it is called Insertion of Clause Code Mixing. The underlineword is clause and independent or can stand alone. It means when you are asking someone opinion about something.

\section{Twitter}

Twitter is the most popular social media platform in the world, with millions of users from various sorts of social media accounts in Indonesia. "Twitter is social networking that allows its users to broadcast their current updates," according to CrunchBase (2012). "Twitter is a microblog service that allows users to send a text message with a maximum length of 140 characters via Short Message Services (SMS), instant message sender, and electronic mail," according to Hadi (2010). Experiences, expertise, and ideas may all be shared through social media. Following that, Twitter is a social networking platform that allows users to change their status, share photographs and videos, and send direct messages to others. As a result of Twitter's trending capabilities, users can see what is trending in Indonesia. Furthermore, people are introduced to new topics that are relevant to them.

The researcher evaluates several past studies linked to the researcher on sociolinguistics, particularly code mixing, in this study. "An Analysis of English Code Mixing Used in Social Media (Instagram)" by Universitas Islam Riau students Ayu Rahmatika (2018). The findings of this study revealed that code mixing serves a variety of objectives in social media platforms such as Instagram. They are the prestige-seeking motivation, the need-satisfying motive, the assertion of status, pride, and authority, the want to be more informational, the desire to make jokes, and the desire to exhibit self-emotion. Diana Kartini (2019) students of The State of Islamic University entitled "Code Mixing Used by Sheryl Sheinafia's Followers (Case Study of Anak Jaksel Language Trend)". The researcher found the several forms of code-mixing that appeared in Sheryl's Twitter account were nouns, adjectives, verbs, and phrases. While the reasons for using Code-Mixing used by Sheryle's followers such as: Dominance attitude and Language Attitude.

\section{METHOD}

This research was conducted using a descriptive qualitative technique. According to (Sugiyono, 2015) qualitative descriptive research produces both oral and written descriptive data. The qualitative technique entails analyzing the data that has been presented; it is a study based on information gleaned from Twitter. The data would be gathered from an influencer's tweet on Twitter. The status that would be collected come from influencers who write mixed language tweet on Tsana (Influencer A), Jiemi Ardian (Influencer B), Mario Teguh (Influencer C), Nago Tejena (Influencer D), Handoko Tjung (Influencer E), Bayu Joo (Influencer F), and Afutami (Influencer G) twitters.

In addition, the forms and goals of code mixing employed in social media Twitter would be described in this study. According to Arikunto (2013), the instrument is a research facility or a tool used by researchers to collect data so that their work may be processed more readily. Documentation is the tool used in this study. Documentation is the process of recording the information obtained from an influencer's tweet on Twitter. 
The researcher employed documented techniques to obtain data from Twitter during the data collection process. Reading Twitter for all influencers that have been captured, identifying the tweet, getting a screenshot of the influencer who used code mixing, and categorizing the data into types of code mixing are the methods used to acquire the data. A descriptive qualitative approach would be used to examine the data, which would look for material concerning code mixing on Twitter. In qualitative research, data analysis entails explicitly conducting organizations. The researcher utilized the following approaches to conduct this analysis: The many types of code mixing have been identified. The many types of code mixing that influencers utilized in their tweets were classified into several categories. Analyzed the data from Twitter influencer's code mixing.

\section{FINDING AND DISCUSSION}

\section{Data Presentation}

The researcher presents his findings and analysis on Indonesian-English Code Mixing in Social Media Twitter. The study looked at several sorts of code mixing and their purposes on the social media network Twitter. Insertion of Word, Insertion of Phrase, Insertion of Hybrid, Insertion of Word Reduplication, Insertion of Idiom, and Insertion of Clause are the several types of code mixing, as described in the previous chapter. Explain why code mixing is used on social media in the second paragraph (Twitter).

Table 1. The Form of Code Mixing found in Social Media Twitter

\begin{tabular}{|c|c|c|}
\hline No. & Form of Code Mixing & Amount \\
\hline 1. & Insertion of Word & 53 \\
\hline 2. & Insertion of Phrase & 20 \\
\hline 3. & Insertion of Hybrid & 8 \\
\hline 4. & Insertion of Word Reduplication & 1 \\
\hline 5 & Insertion of Idiom & 7 \\
\hline 6. & Insertion of Clause & 25 \\
\hline \multicolumn{2}{|c|}{ Total } & $\mathbf{1 1 4}$ \\
\hline
\end{tabular}

\section{Data Analysis}

\section{Insertion of Word}

- $\operatorname{Data}(3)$

"Mau dbikin sampe season 7 juga, tetep aja, yang jauh akan kalah sama yang datang bawa cincin."

The italicized term above is an English word that the influencer used in her tweet. The twitter influencer in this situation employed code mixing. She used the term "season," which refers to a movie episode. Include as a noun in the part of speech season. Insertion of Word is defined as the placement of a season between two phrases.

- Data (12)

"Peribahasa ini mengajarkan buat hati-hati kalo mencoba multitasking." 
It has been discovered that the code is a combination of Indonesian and English. In this example, he used the term multitasking, which refers to performing many tasks at the same time. Multitasking is a noun, not a verb. It can be characterized as word insertion.

\section{Insertion of Phrase}

- $\quad$ Data (7)

"Topik apa yang harus sy selalu hindari bahas agar tidak kena persekuensi massal atau cancel culture?"

Because the statement above contains the terms cancel and culture, some of the words are considered as code mixing Insertion of Phrase. As can be noticed, he uses both Indonesian and English in his speech. He used the term "cancel culture" in his tweet, which refers to a manner of acting in a community or organization, particularly on social media.

- Data (14)

\section{"Terus anaknya di induce ke hypnotic state."}

In data 14, it can be found that the influencer used word hypnotic state in his tweet. It can be classified into insertion of phrase because consist of two words hypnotic and state.

\section{Insertion of Hybrid}

- Data (1)

"Tidak mudah, tapi coba-able."

The italic word above English hybrid used by the influencer as a part ofhis tweet. In this case, the influencer of twitter used code mixing in his tweet, he used English word coba-able that means is hybrid because consists of two language which combine coba- in Indonesia is prefix, and able in English is adjective.

- Data (45)

"Tidak ada orang yang berhak merebut kesempatan untuk mulai berubah pada diri klien, bahkan psikolog-nva sekalipun."

The influencer inserted word psikolog-nya here included category of hybrid base on hybrid affixation. The word psikolog-nya consists of two language which combine the word psikolog is English and the word-nya is Indonesia suffix.

\section{Insertion Of Word Reduplication}

\section{- Data (75)}

"Hidup banyak masalah ngeluh. Hidup flat-flat aja ngeluh juga."

There are terms in the statement that are a mix of Indonesian and English, according to the text above. It's worth noting that he used the term flat twice in the statement, indicating that he utilized a sort of Word Reduplication. The word "flat-flat" alludes to ordinary life or the absence of hurdles. It's known as Insertion of Word Reduplication because he used the English word flat-flat between the captions. The word flat-flat is spelled in English, but its structure and concept are Indonesian.

\section{Insertion Of Idiom}

- Data (35) "Beli Sesuatu Yang Dipengen Tapi Sebenernya Ngga Butuh2 Banget Adalah boros yang dibalut self reward." 
The influencer utilized the phrase "self-reward" in the statement, as can be noticed. It's termed idiom insertion since it contains the terms "self" and "prize." A reward or treatment given by someone for completing a job or attaining a goal is referred to as self-reward.

- Data (94) "Siang under pressure.

There are certain terms in Data 94 that are characterized as code mixing idiom insertion. He used the term "under pressure" in his tweet, implying that he wanted to tell the reader that the term "under pressure" indicates "in a condition of worry or anxiety due to having too much to accomplish.

\section{Insertion of Clause}

- Data (6)

"Terkadang alasan berubah "demi pacar" ata "demi orang tua" tidak cukup kuat. Do it for yourself first."

According to the influencer tweet, it can be seen that there is a mix of Indonesian and English in the sentence. The sentence of do it for yourself firston the statement it's called insertion of clause because there is a subject and predicate in the sentence. In this clause, the subject is it and the predicate is $d o$. That sentence have meaning do something for yourself, then do it for someone else.

- Data (8)

"Pernah gak berada di fase Ineed a man but not a bovfriend?

The influencer used the sentence I need a man but not a boyfriend in her statement. In this case, the influencer of twitter used code mixing in his tweet,it's called insertion of clause because there is a subject and predicate. In this tweet she want have a man who care about her but not a boyfriend.

\section{The Result of Data}

The researcher employed a documentation to gather data for this study. In this case, the researcher selects data from the indonesian-english code mixing category. The data that will be considered are those that are often used in social media on Twitter, and the data shown below is organized by the kind of code mixing. 
Figure 1. Forms of Code Mixing in Social Media Twitter

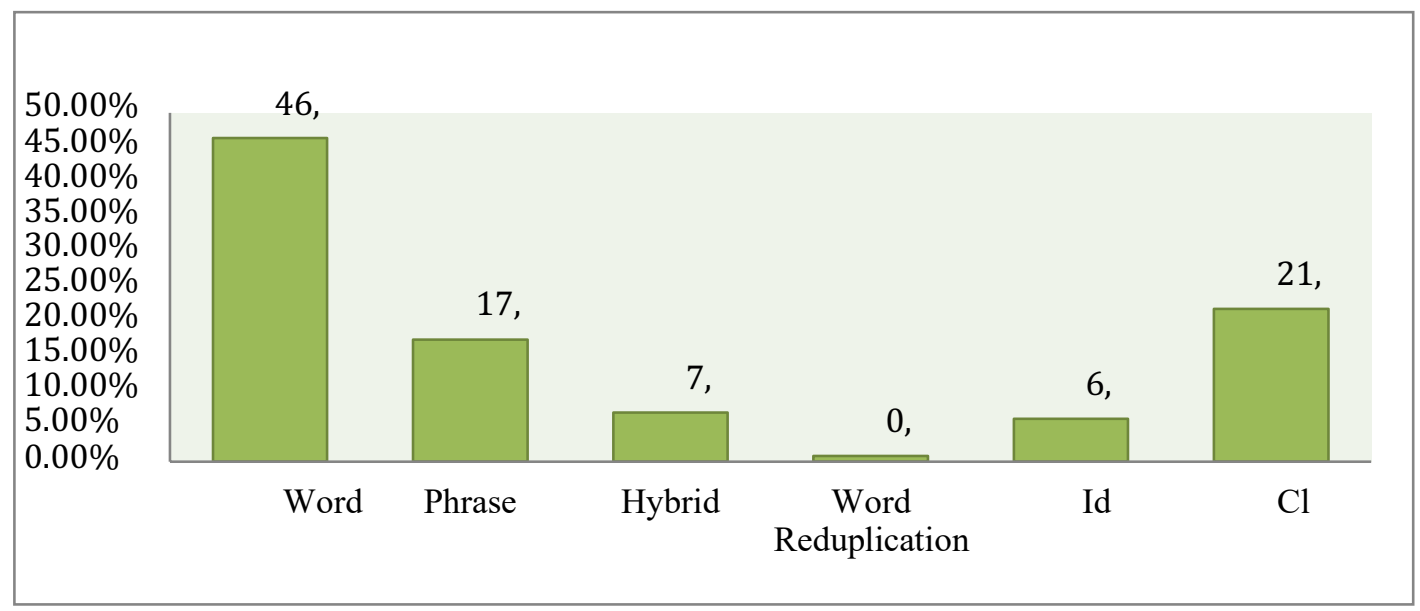

It can be observed from Figure 1 that the influencer on Twitter employed code mixing techniques. They are word insertion, phrase insertion, hybrid insertion, word reduplication insertion, idiom insertion, and clause insertion. In this study, 114 data points were discovered in Indonesian-English code mixing on Twitter.

First, it can be seen that the insertion of word is the highest percentage is $41,4 \%$. In this context, the influencer used the insertion of word in the first, middle, or last in their sentence. The example "Kalau mau diet (mengubah pola makan), fokuskan ke wellbeing dan kesehatan ya." The influencer inserted wordwellbeing in her statement. The word wellbeing is noun. The meaning of word wellbeing is the state of being comfortable, healthy, or happy. The other example "Makasih dah selalu support aku walau aku kl ngerjain sesuatu lama bgt lop." In the influencer tweet, there is word which are classified as code mixing insertion ofword. From the literal meaning, the word support means to agree with and give encouragement to someone. In the part of speech that word include as a verb. The purpose of that example include as need feeling motive.

Second, it can be found that the insertion of phrase have percentage $17,5 \%$. From this research, the example of insertion of phrase is "Makin lama hidup makin ngga pengen macem-macem, cuma pengen good financial aja udah." It can be found that code mixing between Indonesian and English language. The word good financial means have stable finances. That word called insertion of phrase because consist of two words good and financial. Different example of insertion of phrase is "Support system mah ngga usah mulukmuluk, cukup uang aja yang banyak dan ngga abis-abis. "In the context, the influencer mix Indonesian and English language. On his tweet, he used the word support system that means a network of people who provide an individual with practical oremotional support. The category of that word is noun. The purpose of this statement include as need feeling motive.

Third, the percentage of insertion of hybrid is 7,1\%. The example is "Malming2 ngetweet galau ketauan bgt sy single alias bukan jomblo." It can be seen in, the influencer used the word ngetweet in her sentences. The word ngetweet is a hybrid, because the word nge- is Indonesia prefix and the word tweet is English Word. The purpose of that statement is making jokes. Next example "Tidak ada orang yang berhak merebut kesempatan untuk 
mulai berubah pada diri klien, bahkan psikolog-nva sekalipun." The influencer inserted word psikolog-nya here included category of hybrid base on hybrid affixation. The word psikolog-nya consists of two language which combine the word psikolog is English and the word -nya is Indonesia suffix. The pupose is need feeling motive. Then, the percentage of insertion of word reduplication is $0,8 \%$. It was the lowest percentage in the form of code mixing. Only one influencer used insertion of word reduplication. Actually English has no word reduplication. The sense of word reduplication coming from Indonesian language. That word is using Indonesian system and concept but it's written in English. The example is "Hidup banyak masalah ngeluh. Hidup flat-flat aja ngeluh juga." Based on the sentence above, there is word a mix of Indonesian-English in the sentence. It can be seen,he used the word flat-flat is a form of Word Reduplication, because the word flatis written twice in the sentence completely. The word flat-flat means the ordinary life or no challenges. When he used the English word flat-flat between the caption, it's called Insertion of Word Reduplication, because consist of two words. The purpose of that statement is expressing self emotion.

Next, insertion of idion have $6,1 \%$ percentage. Idiom is a group of words in a fixed order that have a particular meaning that is different from the meanings of each word on its own. In this research, the example of idiom is "Beli sesuatu yangdipengen tapi sebenernya ngga butuh2 banget adalah boros yang dibalut self reward." It can be seen, the influencer used the word self reward in the sentence. It's called insertion of idiom because consist of two words self and reward. The word self reward means that a reward or treatment given by someone for completing a task or achieving a goal. The other example "Entah ini fakta apa tidak, tp kucing bisa membuat move on jd lebih mudah." The italic word above is English idiom used by influencer as a part of her tweet. In this context, influencer used code mixing move on that means continue moving. That example include thecategory as expressing self emotion.

Last, percentage insertion of clause is $21,9 \%$. The influencer used insertion ofclause as the main point or to asserting the tweet. The example of insertion of clause is "Kita ga pernah tau isi dalemnya sbnrnya kyk apa, just leave them alone. masa harus selalu kyk apa yg kamu mau." On the sentence above, there is sentence which are classified as code mixing insertion of clause. It can be seen,she mix Indonesian and English language. The sentence just leave them alone which showed that don't care what people do. Next example, "Work life balance. Weekdays kerja siang-siang, weekend tidur siang." In this section, the influencer mix Indonesian and English language. On his tweet, the sentence work life balance is a kind of insertion of clause and dependet clause because can not stand alone. Idiom is a group of words, consisting of a subject and predicate. The tweet of ifluencer include to the category expressing self emotion. In summary, the highest percentage form of code mixing is insertion of word $(41,4 \%)$ used by the influencer on twitter. And then, the lowest percentage $(0,8 \%)$ is insertion of word reduplication. 


\section{CONCLUSION}

Code mixing might occur in every way, when people can speak more than one language and mix those languages. For the reason also code mixing that used in the tweet of social media twitter is interesting to be analyzed. The influencer in twitter used the forms of code mixing. They are insertion of word, insertion of phrase, insertion of hybrid, insertion of word reduplication, insertion of idiom, and insertion of clause. In this research, there are totally 114 data has been found in Indonesian-English code mixing on twitter.

In this research, the researcher found that the insertion of word is the highest percentage $(41,4 \%)$. Second, the insertion of phrase have percentage $(17,5 \%)$. Third, the percentage of insertion of hybrid $(7,1 \%)$. Then, the percentage ofinsertion of word reduplication $(0,8 \%)$. It was the lowest percentage in the form ofcode mixing. Next, insertion of idiom have $(6,1 \%)$ percentage. Last, percentage insertion of clause $(21,9 \%)$.

Based on the code mixing data used by influencer, the researcher found that 4purposes of influencer used code mixing. Firstly, need feeling motive. Some of them used insertion of word in order to express something. Secondly, being more informative. Thirdly, making jokes. And the last is expressing self emotion. Influencer used insertion of clause in order to express their self emotion.

\section{ACKNOWLEDGEMENTS}

First and foremost, the author thanks Allah SWT for granting her favor and providing her with ease, health, strength, and capacity to complete this diary and write this essay named "An Analysis of Indonesian-English Code Mixing Used In Social Media (Twitter)." Furthermore, while writing this essay, the researcher discovered that many individuals provide support, guidance, encouragement, and assistance to them. The researcher is grateful for the advisor and lecturer of Pendidikan Bahasa Inggris FKIP UIR's encouragement, support, and advice.

\section{REFERENCES}

Arikunto, Suharsimi. (2013). Prosedur Penelitian Suatu Pendekatan Praktik. Jakarta: Rineka Cipta.

CrunchBase. (2012). Twitter. Retrieved February 2, 2012, from TechCrunch: $\mathrm{http}: / / \mathrm{www}$. crunchbase.com/co mpany/twitter.

Hadi, Mulya. (2010). Twitter untuk Orang Awam. Palembang: Maxikom.

Hanafiah, R., Rantika, A., \& Yusuf, M. (2018). The Levels of English-Arabic Code-Mixing in Islamic Boarding School Students' Daily Conversation. Advances in Language and Literary Studies, 9(6), 78. https://doi.org/10.7575/aiac.alls.v.9n.6p.78

Hamers, F. J \& Blanc, H.A.M. 1987. Bilinguality and Bilingualism. Cambridge: Cambridge University Press, Retrieved on February 16, 2009 from www.google.com.

Kartini, D. (2019). Code Mixing Used By Sheryl Sheinafia's_Followers (Case Study Of Anak Jaksel Language Trend) (Doctoral Dissertation, Islamic University).

Kim, E. (2006). Reason and Motivations for Code-Mixing and Code-Switching. TESOL Journal. Vol.4, No.1.43-61. 
Krutka, D. G. (n.d.). How_and_why_educators_use_twit.PDF.

Pratapa, A., Bhat, G., Choudhury, M., Sitaram, S., Dandapat, S., \& Bali, K. (2018). Language modeling for code-mixing: The Role of Linguistic Theory based Synthetic Data. $A C L$ 2018 - 56th Annual Meeting of the Association for Computational Linguistics, Proceedings of the Conference (Long Papers), 1, 1543-1553. https://doi.org/10.18653/v1/p18-1143

Rahardi, Kunjana. (2010). Sosiolinguistik Kode dan Alih Kode. Bogor: Ghalia Indonesia

Siskawati, N. (2012). Code Mixing Found in C'est La vie Novel. Journal on English Language, Culture and Literature. Diponegoro: Diponegoro University.

Sugiyono. (2015). Metode Penelitian Pendidikan Pendekatan Kuantitatif, Kualitatif, dan $R \& D$. Bandung: Alfabeta.

Surtrismi. (2014). the Use of Indonesian English Code Mixing in Social Media. PUBLICATIONS_ARTICLE.pdf (ums.ac.id)

Wardhaugh, R. (2006). An Introduction to Sociolinguistics fifth edition. Oxford: Blackwell Ltd.

Wardhaugh, Ronald and Janet M. Fuller. (2015). An Introduction to Linguistics Seventh Edition. 